Article

\title{
Analysis of Application Parameters of Hydraulic Slotting Technology in Jointed Coal Reservoirs
}

\author{
Zhaolong Ge ${ }^{1,2}$, Shaojie Zuo ${ }^{1,2}{ }^{-}$, Yingwei Wang ${ }^{3, *}$, Youchang Lyu ${ }^{3}$ and Xinyan Feng ${ }^{1,2}$ \\ 1 State Key Laboratory of Coal Mine Disaster Dynamics and Control, Chongqing University, \\ Chongqing 400044, China; gezhaolong@cqu.edu.cn (Z.G.); shaojie@cqu.edu.cn (S.Z.); \\ fengxinyan521@gmail.com (X.F.) \\ 2 School of Resources and Safety Engineering, Chongqing University, Chongqing 400044, China \\ 3 State Key Laboratory of Coking Coal Exploitation and Comprehensive Utilization, Pingdingshan 467000, \\ China; lvuyouchang@163.com \\ * Correspondence: wangyingwei.w@gmail.com
}

Received: 4 November 2019; Accepted: 9 December 2019; Published: 16 December 2019

check for updates

\begin{abstract}
Hydraulic slotting technology is typically used in coal mines to enhance permeability and prevent gas outbursts. Because a coal seam contains many cleats and joints, this study investigated the influence of conventional application parameters on the hydraulic slotting effect by numerical simulation and experimental testing. The cleats in the coal generated stress concentration and initiated with the water jet impact, which promoted the formation of a complex fracture network. The optimized arrangement included angles with an inclination of $20-45^{\circ}$ between the borehole and the coal seam strike. The water jet pressure and rotation speed determined the shape of the slot. A high water jet pressure and low rotation speed promoted the formation of cracks at the end of the slot and strengthened the permeability-enhancing effect. Coal fragments could more easily peel off from the sides of the seam and block the borehole. The high water pressure and low rotation speed application parameters were optimized without blocking the borehole. Results obtained by field application revealed that the gas extraction flow after optimization was 1.3 times that of conventional hydraulic slotting. An appropriate angle between the cleats and borehole can more effectively increase the permeability of the coal seam and results in higher gas drainage flow. The results of this study can be useful as guidelines for field applications of hydraulic slotting technology.
\end{abstract}

Keywords: hydraulic slotting; water jet; permeability enhancement; gas exploitation; crack initiation

\section{Introduction}

Coalbed methane (gas) is a new form of clean energy stored in coal seams [1-4]. According to statistics, the global gas resources buried at a depth of less than $2000 \mathrm{~m}$ amount to 240 trillion cubic meters, which is twice that of conventional natural gas resources and has great exploitation potential [5-7]. Moreover, gas exploitation can effectively prevent and control coal and gas outbursts, and reduce production accidents during coal mining $[8,9]$. China has the third largest gas reserves in the world. However, most coal mines in China are characterized by complex geological structures and low-permeability coal seams, which makes the effective extraction of gas difficult using traditional technologies. Currently, hydraulic fracturing technology and water jet slotting technology are typically used for the enhancement of coal-seam permeability [10,11]. Hydraulic fracturing technology has effective applications; however, various shortcomings, such as high initiation pressure and the existence of non-fractured areas, still exist and prevent the application of this technology to coal seam structures because they may induce outburst accidents $[12,13]$. To a certain extent, water jet slotting technology 
can significantly improve the effect of gas extraction and is applicable to all coal seams. Moreover, it is currently an indispensable technology for enhancing the permeability of coal seams [11,14].

To investigate the permeability-enhancing mechanism of hydraulic slotting and optimize the hydraulic slotting effect, many studies produced relevant investigations by experimental tests. Lin et al. [15] implemented hydraulic slotting in the Wangxingzhuang coal mine in China and found that the effective diameter and average gas-extraction concentration of the slotted borehole were approximately 12.8 and 3.7 times those of a conventional borehole. Additionally, their results revealed that the hydraulic slotting technique is effective. Jiang et al. [16] proposed different hydraulic slotting techniques and carried out field tests. Their results revealed that the average gas-extraction concentration increased by more than two times. Zhang et al. [17] derived the velocity distribution law and the pressure attenuation law of a water jet based on theoretical analysis, and established a maximum slot depth prediction model. Additionally, the error range of the field test results and maximum slot depth prediction model was less than $10 \%$. Zou et al. [18] tested and analyzed the coal parameters before and after hydraulic slotting and coalbed methane pre-drainage, and reported that the effective stress of the coal seam sequentially changed during the slotting and pre-drainage processes, and that the pore proportion and coalbed methane adsorption properties of the coal changed significantly. Zou et al. [19] established a fluid-solid coupling test system, which provided real air pressure and stress, and used it to simulate the entire hydraulic slotting extraction process. In this experiment, the law governing the stress variation during the slotting process was analyzed, and the deformation characteristics and gas migration were obtained with different slotting parameters. For numerical simulation, many scholars analyzed fluid-solid coupling by extended and generalized finite element methods [20,21]. In order to make the numerical simulation results more accurate, Prevost et al. [22,23] used an extended finite element method to study fluid-solid coupling, and optimized the couplings between stress and pressure. Liu et al. [24] and Rivas et al. [25] used an extended finite element method optimized in different ways. In the numerical simulation of hydraulic slotting technique, Zhang et al. [26] investigated the self-excited oscillation pulsed jet slotting technology by conducting a numerical simulation, and proposed and analyzed a cross slotting arrangement to reduce the slotting construction. The field test results revealed that the cross-slotting arrangement doubled the coal roadway tunneling speed. Lin et al. [27] simulated hydraulic slotting using different lateral pressure coefficient models developed by the Particle Flow Code, and investigated the crack propagation patterns and kinetic energy evolution laws with different lateral pressure coefficients. Kong et al. [28] obtained the laws governing the influence of the slotting radius, gas pressure, and coal seam permeability on the effective influence radius by carrying out a numerical simulation. They reported that the effective radius was positively correlated with the slotting radius and permeability, and negatively correlated with the gas pressure. Additionally, the stress distribution near the borehole was consistent with the gas pressure distribution.

However, the aforementioned studies did not consider the cleats and joints in coal seams, and only considered the basic theory and technical principle of hydraulic slotting technology to increase the coal seam permeability. Moreover, previous studies have not provided suggestions and guidelines for the application of hydraulic slotting technology to jointed coal reservoirs. The typical hydraulic slotting application parameters are the borehole angles, water jet pressure, and rotation speed. In this study, we investigated the law governing the influence of the application parameters on the hydraulic slotting effect by carrying out numerical simulation and experimental testing. Various suggestions for practical applications are provided in this paper.

\section{Optimization of Borehole Angles}

According to existing research, many natural cleats and joints exist in coal seams $[29,30]$. These cleats and joints are vertically distributed in the coal seam and form a stereo network [31,32], as shown in Figure 1. According to the microscopic damage mechanics theory of micro-cracks, the continuous impact of the water jet on the coal rock causes stress concentration and crack initiation around the 
cleat tip in the coal. In the case of a fixed nozzle, the optimization of the water jet impact direction and pump pressure can affect the stress concentration around the cleats and joints. Then the cleats and joints will be initiated and stimulate the permeability. In hydraulic slotting, the water jet direction is perpendicular to the borehole; therefore, the water jet direction can be optimized by optimizing the borehole angle. Because the initiation of the cleat tip cannot be monitored experimentally, a numerical simulation was carried out for analysis. We investigated the pump pressure and transverse speed by carrying out the experimental testing described in the next section.

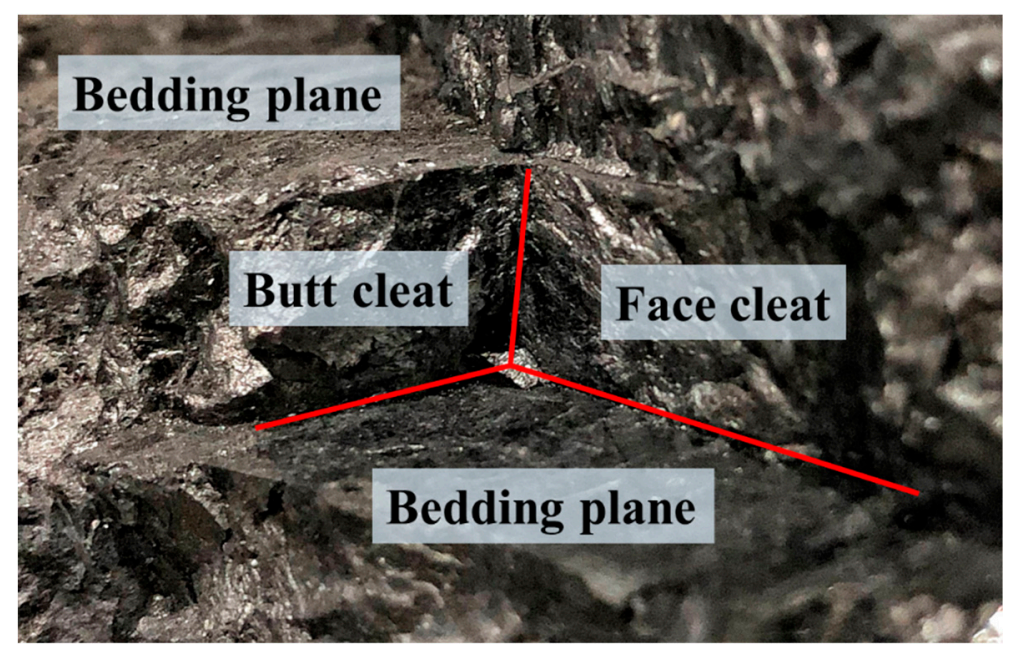

Figure 1. Cleat system in coal seam.

\subsection{Crack Initiation Criteria}

This section discusses the determination of the crack initiation criteria by numerical simulation and theoretical analysis. Crack initiation and propagation under water jet action results in brittle failure. Therefore, the damage mode of a single type-I static micro-crack was used to investigate the propagation rule of cracks in coal under the action of a high-pressure water jet. To simplify the calculations, the following assumptions were made [33]:

(1) The damage in the coal is caused by the propagation of cracks under the combined action of a high-pressure water jet impact force and quasi-static pressure.

(2) New cracks are not produced during the coal-slotting process. Stress concentration and crack initiation will be caused around the cleat tip in the coal.

(3) The interaction between the slot and cleats was not considered.

(4) The hydro-mechanical coupling between water and coal is neglected.

Therefore, using the type-I crack initiation criterion, the criterion for crack damage under the action of a water jet is expressed as follows:

$$
K_{\mathrm{I}}^{\infty}=K_{\mathrm{I} c}
$$

When $K_{\mathrm{I}} \geq K_{\mathrm{Ic}}$, the crack is initiated; $K_{\mathrm{I}}$ can be calculated as follows:

$$
K_{\mathrm{I}}=\left(\sigma_{x} \cos ^{2} \theta+2 \tau_{x y} \sin \theta \cos \theta+\sigma_{y} \sin ^{2} \theta\right) \sqrt{2 \pi r}
$$

where $K_{\mathrm{I}}$ is a type-I stress intensity factor; $\sigma_{x}, \sigma_{y}$ and $\tau_{x y}$ denote the stress on the cleat; $r$ is the distance from a node, close to the cleat tip; $\theta$ is the angle between the cleat and $\sigma_{y}$.

\subsection{Establishment of Model}

The finite element method is utilized to analyze the stress around the natural cleat. The numerical model was established based on the $\mathrm{J}_{15}$ coal seam in the Pingdingshan No.12 Coal Mine in Henan 
province, and the coal seam parameters are listed in Table 1. To analyze the propagation rule of the cleat under the action of a high-pressure water jet, a single cleat was preset in the model. This cleat had different included angles to the normal direction of the high-pressure water jet $\left(0^{\circ}, 15^{\circ}, 30^{\circ}, 45^{\circ}\right.$, and $60^{\circ}$, respectively). The length, width, and height of the model were $300 \mathrm{~mm}$, and the cleat length was $165 \mathrm{~mm}$. The cleat is simulated by setting a tiny width void in the model. The model was divided into a total of 327,300 units and 346,086 nodes. According to the research of some scholars [34-36], the size of the mesh affects the value of the result, but does not affect the change rule of the value. The purpose of this simulation mainly analyzes the stress change rule close to the cleat tip. The model with 327,300 units was valid to analyze the stress change rule around the cleats without using large computational resources. The top surface of the model was subjected to a ground stress load at a depth of $550 \mathrm{~m}(7.5 \mathrm{MPa})$, and the bottom and side surfaces were constrained. The vertical stress in the slot was set to $20 \mathrm{MPa}$ to simulate water jet impact force. The numerical model was established as shown in Figure 2.

Table 1. Basic parameters.

\begin{tabular}{cc}
\hline Properties & Values \\
\hline Young's Modulus (MPa) & 1750 \\
Poisson's ratio $^{-3)}$ & 0.3 \\
Density $\left(\mathrm{kg} \cdot \mathrm{m}^{-3}\right.$ & 1400 \\
Internal friction angle $\left(^{\circ}\right)$ & 23 \\
Uniaxial compressive strength $\left.(\mathrm{MPa})^{1 / 2}\right)$ & 13 \\
Fracture toughness $\left(\mathrm{MPa} \cdot \mathrm{m}^{1 / 2}\right.$ & 0.11 \\
Initial porosity & 0.0186 \\
\hline
\end{tabular}

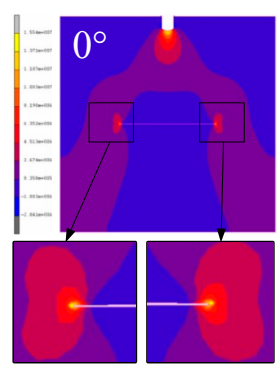

(a)

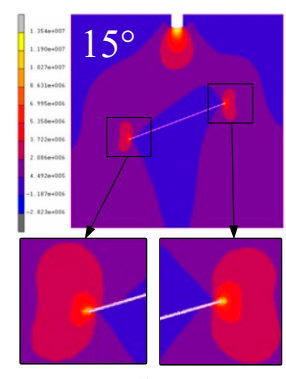

(b)

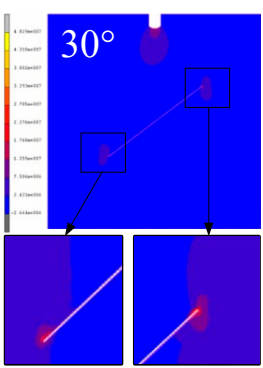

(c)

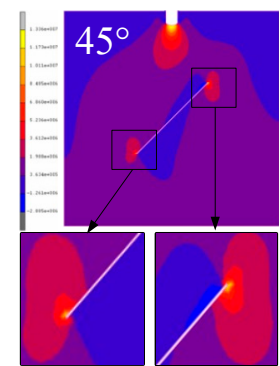

(d)

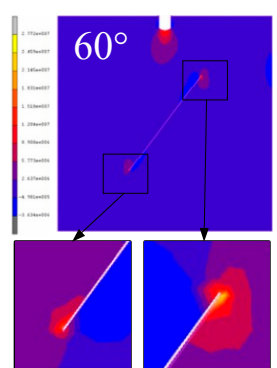

(e)

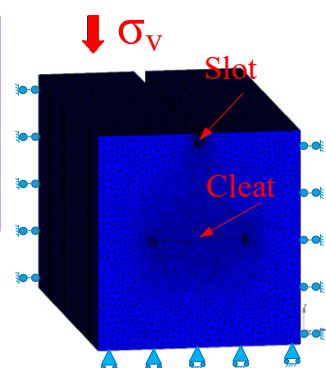

(f)

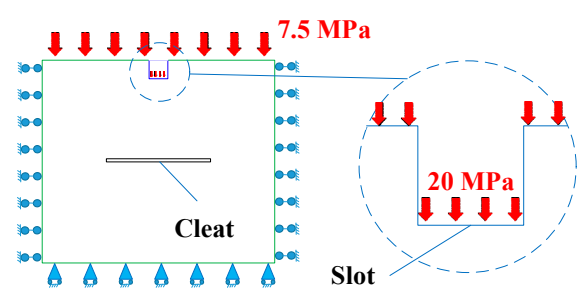

(g)

Figure 2. Numerical simulation diagram: (a-e) cloud diagram of axial tensile stress with different included angles; (f-g) diagram of numerical simulation model.

\subsection{Simulation Results and Analysis}

According to the axial tensile stress cloud diagram shown in Figure 2, under the action of a high-pressure water jet, the stress concentration area and maximum stress of the cleat with different included angles occurred at the cleat tip. In the simulation, the stress at the cleat tip was obtained. The maximum values of the different stresses are shown in Figure 3. The values of the axial tensile 
stress were maximum; that is, under the same water jet pressure, the axial tensile stress was the first to reach the tensile strength of the material. Additionally, the cleat in the coal seam was initiated by tensile failure. Moreover, according to Griffith's theory, the cleat expanded along the axial tensile stress direction, which was the vertical direction of the natural cleat.

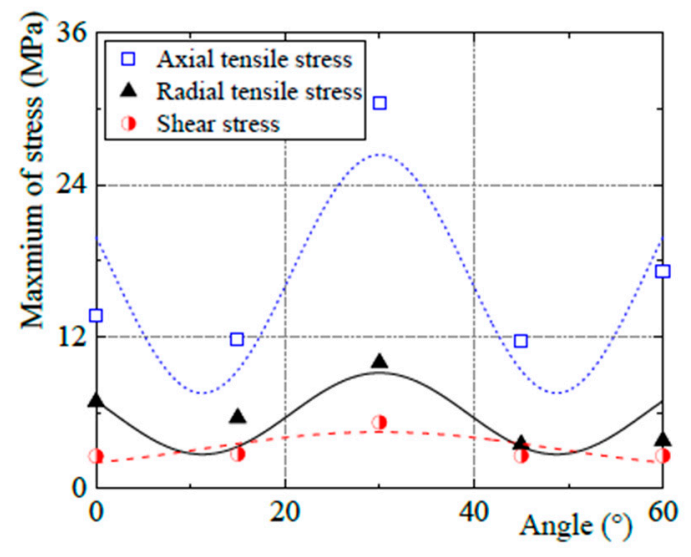

Figure 3. Stress of cleat tips in different models.

To further investigate the cleat initiation, the $\mathrm{K}_{\mathrm{I}}$ values at different points close to the cleat tip were calculated using Equation (2). The $\mathrm{K}_{\mathrm{I}}$ values of the cleat tip at different included angles were obtained using the least squares method to fit $\mathrm{K}_{\mathrm{I}}$ and obtain the regression line. The $\mathrm{K}_{\mathrm{I}}$ fitting results for the cleats tips with different included angles are presented in Figure 4, and the $\mathrm{K}_{\mathrm{I}}$ values at the tips are shown in Figure 5. As can be seen, the $\mathrm{K}_{\mathrm{I}}$ values at both tips of the $0^{\circ}, 15^{\circ}$, and $30^{\circ}$ models exceeded the fracture toughness of the coal, and cleats were initiated from both cleat tips. In the $45^{\circ}$ model, only the $\mathrm{K}_{\mathrm{I}}$ value of the right tip exceeded the fracture toughness, and the cleat initiated from the right tip. Because the $\mathrm{K}_{\mathrm{I}}$ values at both tips of the $60^{\circ}$ model did not exceed the fracture toughness of coal, the cleat did not initiate.
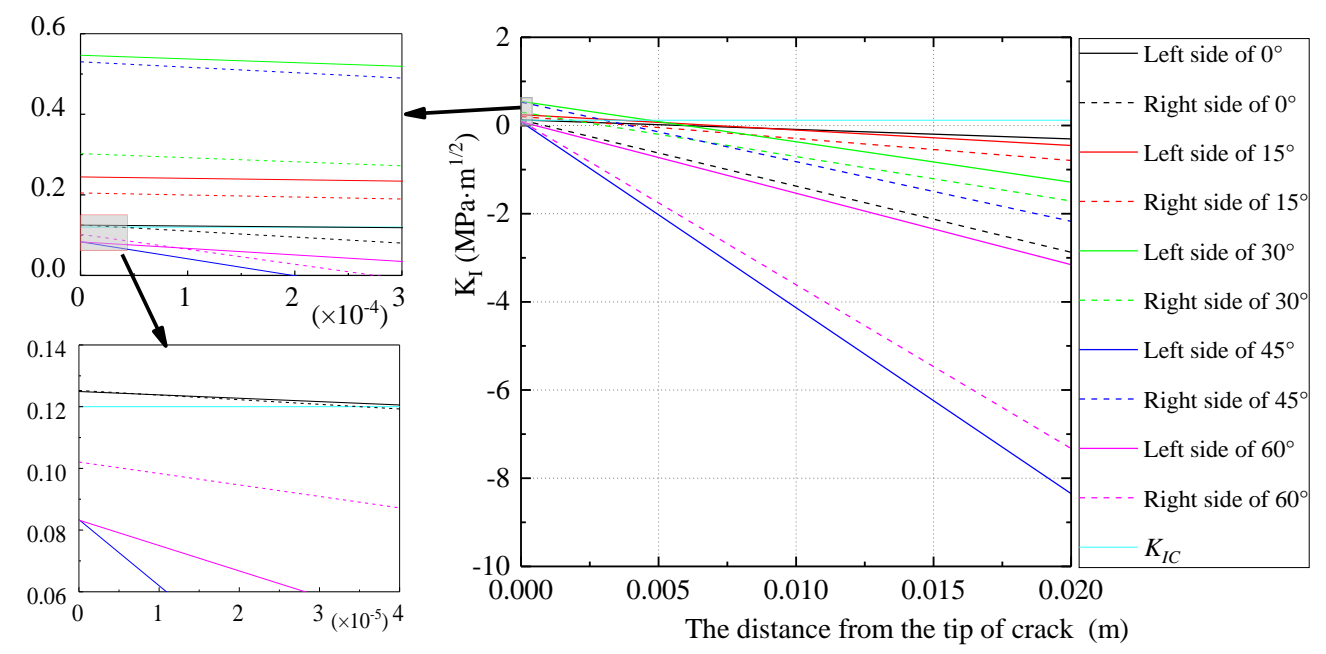

Figure 4. Fitted $\mathrm{K}_{\mathrm{I}}$ curves of different models. 


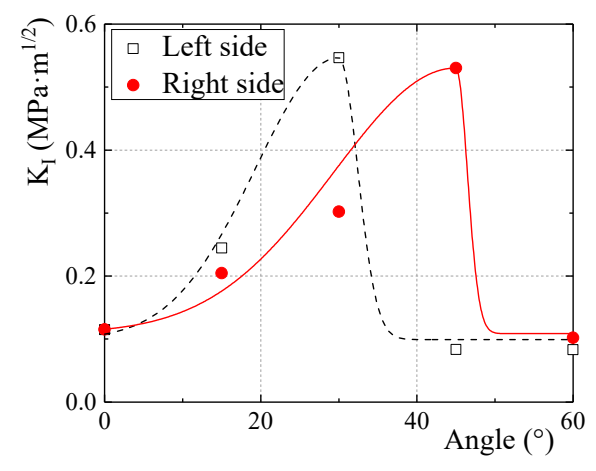

Figure 5. $\mathrm{K}_{\mathrm{I}}$ of different models.

As shown in Figure 5, under water jet action, the cleats at a small included angle to the normal direction of the high-pressure water jet were easier to initiate. The stress intensity factor $\mathrm{K}_{\mathrm{I}}$ was larger at the cleat tip of $20-45^{\circ}$. Both cleat tips were more prone to initiate at $30^{\circ}$. Additionally, the cracks extended along the axial tensile stress direction. To make the slot and cleats inside the coal seam connect with each other, the slotting borehole should be drilled at a small angle to the cleats. The beddings and cleats in the coal seam were perpendicular to each other. Therefore, the optimal arrangement parameter was the inclination of $30^{\circ}$ for the included angles between the borehole and the coal seam strike. Thus, the water jet impact was beneficial to the development of cleats and beddings.

\section{Optimization of Slotting Parameters}

In the process of continuous water jet impact on coal and rock, a large number of cracks are produced, and this greatly improves the permeability of the coal seam. Theoretically, as the pump pressure increases, the slotting effect improves. However, during field applications, various problems may appear if the pump pressure is high. The rotation slotting speed and pump pressure are the typical hydraulic slotting application parameters. Experimental testing is an effective method for investigating field applications and determining the appropriate pump pressure. The size of the slot and the crack development in the coal were investigated using computerized tomography (CT) scanning technology. The specimen was made as a briquette to eliminate the influence of natural cracks (pre-existing cleats) on the results. The strength of the specimen was low. When the water jet impact is oblique, the impact force of the water jet will damage the specimen. Eventually a wedge-shaped pit will form instead of a slot. Therefore, we did not research the effect of incident angle in this experiment, and the water jet incident angle was set at $90^{\circ}$.

\subsection{Test System and Specimen Preparation}

The experimental model was established on the basis of the $\mathrm{J}_{15}$ coal seam, which had a depth of 500-600 m. The coal seam was soft and had broken coal, which increases the risk of coal and gas outbursts. Because the coal seam was very soft, a large piece of raw coal could not be obtained. The specimen consisted of pulverized coal, clay, and water at a mass ratio of 1:0.6:0.1. The compressive strength of the specimen was $1.28 \mathrm{MPa}$, and the elastic modulus was $0.063 \mathrm{GPa}$. As shown in Figure 6, the specimen was a cube with a size of $200 \times 200 \times 200 \mathrm{~mm}$, and required drying at $50-60{ }^{\circ} \mathrm{C}$ for 10 days.

In field applications, high-pressure water jet slotting is carried out in the drilling borehole. Nozzle rotating slotting takes place at a fixed target distance. Therefore, the effect of the target distance was not considered in this experiment. According to the actual situation and equipment conditions, the target distance was $165 \mathrm{~mm}$ and the nozzle diameter was $2.5 \mathrm{~mm}$. The influencing factors considered in the experiment were the water jet pressure and rotation speed. Owing to equipment limitations, the transverse speed was used to investigate the rotation speed. 


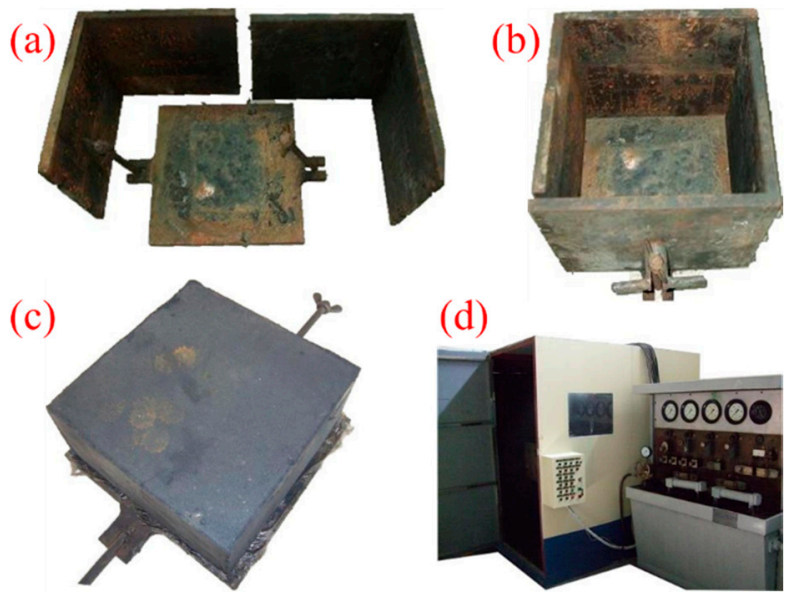

Figure 6. Specimen processing and equipment: (a) decomposed mold; (b) assembled mold; (c) specimen; (d) water jet test and control system.

\subsection{Effect of Slotting Parameters on Slot Shape}

\subsubsection{Effect of Pump Pressure on Slot Shape}

In the experimental investigation of the water jet pressure, the slotting speed was set to $0.12 \mathrm{~m} / \mathrm{s}$; the slot shape is shown in Figure 7. As can be seen, the slot width did not change significantly with different water jet pressures, and was approximately $15 \mathrm{~mm}$. However, the slotting depth greatly varied with the change of water jet pressure. When the water jet pressure was $5 \mathrm{MPa}$, only shallow grooves were crushed on the specimen's surface. When the water jet pressure was $22 \mathrm{MPa}$, the specimen was slotted into two parts. Mainly because the impact force of the low-pressure jet was weak, the energy generated by the water jet could not reach the threshold required for coal destruction, and the slot depth was shallow. When the jet pressure exceeded the damage threshold, the depth of the slot increased significantly. Moreover, the transverse movement provided the jet with transverse velocity, and thus the water jet flow exerted a transverse shear force to the coal and aggravated the coal destruction. However, when the impact depth of the water jet reached a certain level, the water in the slot formed a cushion, which attenuated the jet energy and velocity, and thus rendered the water jet incapable of damaging the coal. In other words, the ultimate depth of the water jet slot was reached. Owing to the limited experimental conditions, a deeper slot depth could not be obtained in this experiment. The slot depth $h$ and water jet pressure $P_{w}$ are fitted in Figure 8. According to the data obtained, the slot depth and exposed area increased within a certain range with the water jet pressure, which indicates a quadratic positive correlation.
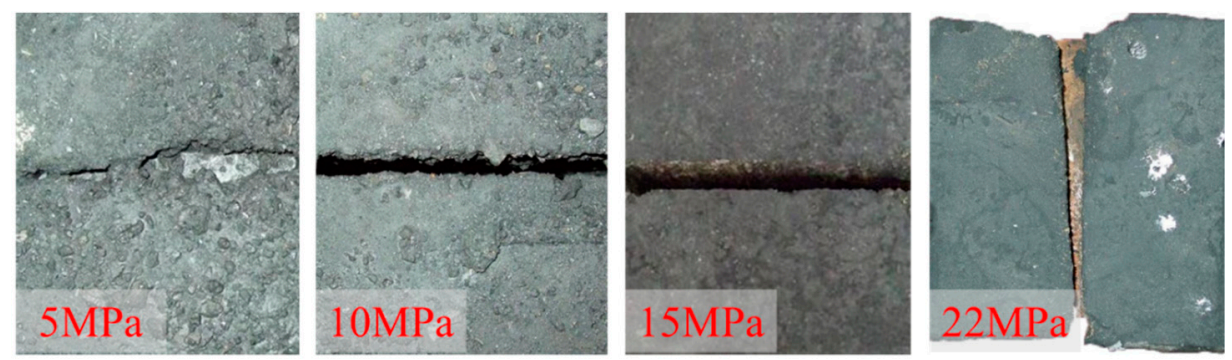

Figure 7. Specimen under different water jet pressures. 


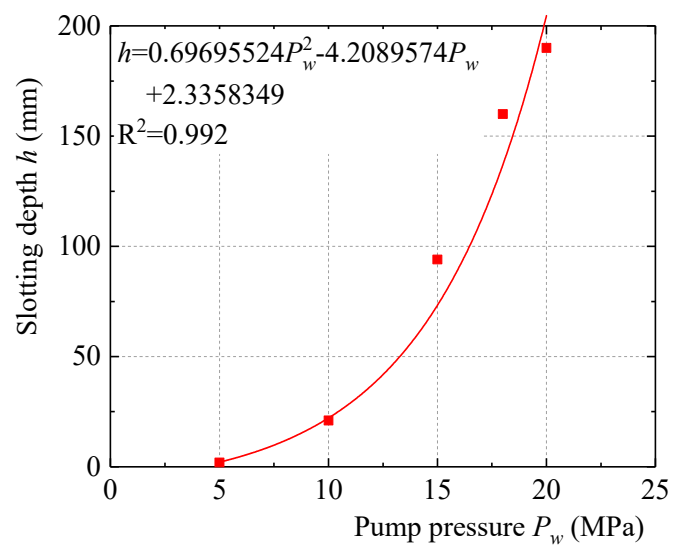

Figure 8. Relationship between slotting depth and water jet pressure.

Moreover, it was observed that various fragments peeled off from the two edges of the slot when the water jet pressure was $22 \mathrm{MPa}$. This is mainly attributed to the fact that the impact effect increased with the water jet pressure. During the slotting process, stress waves are generated $[37,38]$. The reflection and superposition of these stress waves generate tensile stress on the specimen. Additionally, the tensile stress increases with the increase of water jet pressure, and promotes the destruction of coal. Furthermore, the water in the slot is discharged outward and forms a water cushion under the water jet impact, which exerts an impact force on both sides of the slot. When the impact reaches a certain extent, various coal fragments peel off. The depth of the slot is one of the main factors affecting the slotting effect. As the water jet pressure increases, the slot depth becomes greater, the pressure relief area of the coal seam becomes larger, and the permeability-enhancing effect improves. However, high water jet pressure leads to large fragments being peeled off from the edge of the slot. This makes it difficult to discharge the slag, and causes the problems of boreholes being stuck and collapsing. Therefore, there exists an appropriate water jet pressure value, and this appropriate pressure should be determined according to the firmness coefficient of the coal seam.

\subsubsection{Effect of Transverse Slotting Speed on Slot Shape}

The transverse slotting speed is the rotation speed of the drill bit during water jet slotting. When the water jet pressure was $15 \mathrm{MPa}$, the speed became faster, and the slot became shallower. When the transverse speed was $0.09 \mathrm{~m} / \mathrm{s}$, the specimen was deeply slotted. When the transverse speed was $0.06 \mathrm{~m} / \mathrm{s}$, the specimen was slotted through. Moreover, the transverse speed had a minor effect on the slot width, which was approximately $15 \mathrm{~mm}$. The slot depth $h$ and traverse speed $v$ are fitted in Figure 9. Within a certain range, the slot depth and exposed area decreased as the traverse speed increased, and the decay rate became progressively smaller.

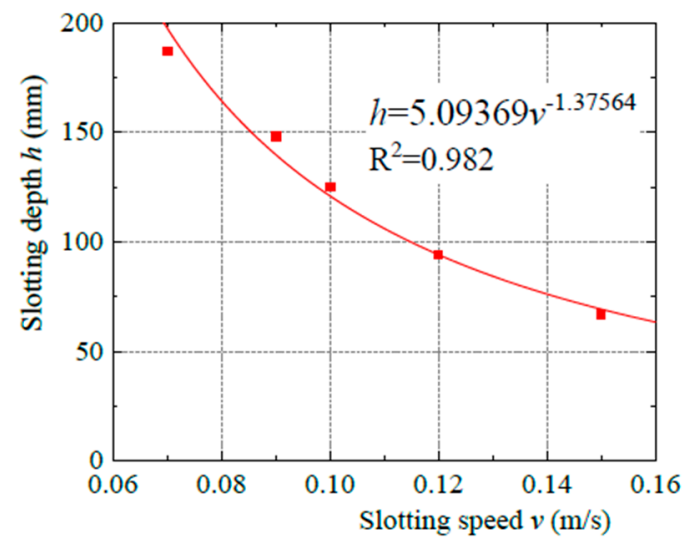

Figure 9. Relationship between slotting depth and slotting speed. 
Similarly, when the transverse speed was $0.06 \mathrm{~m} / \mathrm{s}$, the phenomenon of some coal fragments peeling off at the edge of the slot was observed. This means that the problems of stuck and collapsing boreholes were also induced when the transverse slotting speed decreased. Additionally, as the traverse speed decreased, the time of the water jet impacting the coal increased, and the superposition of the stress waves and the water cushion effect became more obvious. The coal at the edge of the slot received more energy, and the coal fragments promoted the peel-off. Therefore, there exists an appropriate transverse slotting speed value, which should also be selected according to the firmness coefficient of the coal seam.

\subsection{Effect of Slotting Parameters on Crack Development}

To observe the development of cracks in the coal after slotting, the coal was scanned before and after slotting using CT. Because the specimen was artificial and consisted of pulverized coal and clay, there were no natural cracks and only a few pores existed in the specimen. There are two types of CT scanning for specimens, namely, plane scanning, and vertical scanning. In Figure 10, plane scanning is denoted as type I, and was carried out perpendicularly to the direction of the water jet slotting; the vertical scanning is denoted as type II, and was carried perpendicular to the transverse direction of the water jet.

In Figure 10, it can be clearly seen that various coal fragments peeled off from the edge. When the water jet pressure was low, the shape of the slot was relatively complete. As the pressure increased, the fragment peel-off also increased and the shape of the slot became more uneven. The specimens slotted by $15 \mathrm{MPa}(0.09 \mathrm{~m} / \mathrm{s})$ and $20 \mathrm{MPa}(0.12 \mathrm{~m} / \mathrm{s})$ were not split into two parts, but cracks existed at the ends of the slot inside the specimen, and formed a splitting trend.
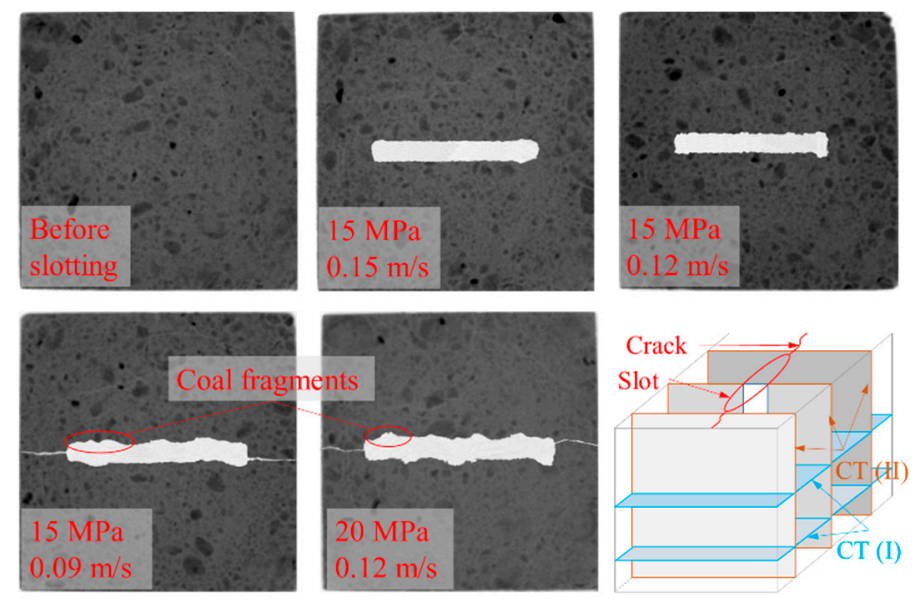

Figure 10. CT scanning image of slots.

To observe the crack morphology, CT (type II) scanning was carried out at the end of the slot at 6-mm intervals as shown in Figure 11. The crack was essentially a vertical crack, and the propagation direction was the water jet transverse direction. Additionally, certain distortion existed in the crack propagation process, which increased the coal's permeability. This indicates that, as the hydraulic slotted pressure increased, the slotted time became longer, and new cracks were more likely to form. Therefore, the water pressure could appropriately increase, provided that the peeled-off coal did not block the hole. The results revealed that the slotting time and pump pressure were the main factors affecting crack development. 


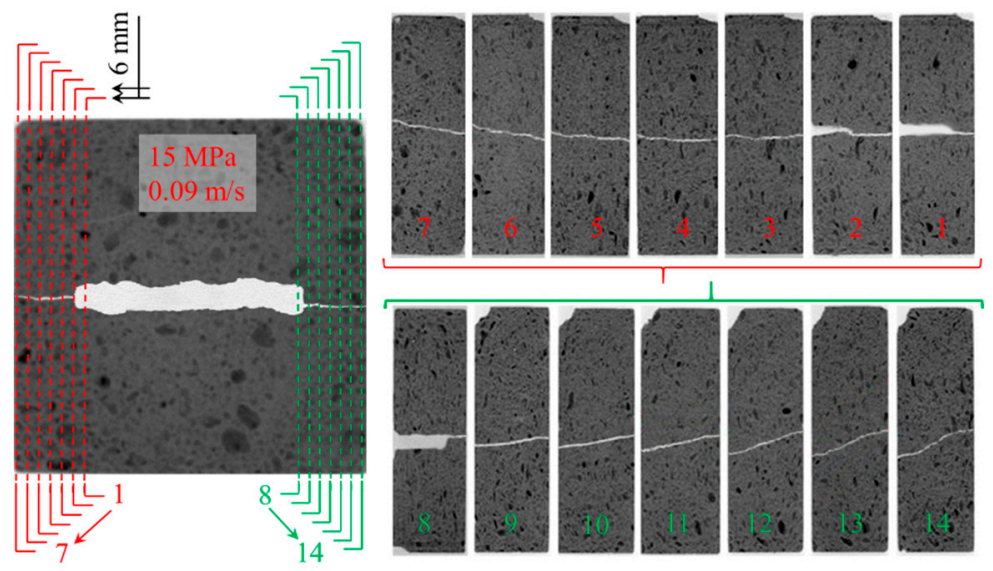

Figure 11. Vertical CT scan image of slots.

\section{Field Application}

\subsection{Application Details}

To verify that the permeability enhances the effect of water jet slotting, a field experiment was conducted in the $\mathrm{J}_{15}$ coal seam in the Pingdingshan No. 12 Coal Mine in Henan province. The average thickness of the coal seam was $3.2 \mathrm{~m}$, and the inclination angle was $6^{\circ}$. The gas pressure of the coal seam was $1.7 \mathrm{MPa}$, and the gas content was $17.4 \mathrm{~m}^{3} / \mathrm{t}$. Three types of boreholes were considered in this test: optimized slotted borehole, conventional slotted borehole, and conventional borehole. The application parameters for the conventional slotted borehole were $20 \mathrm{MPa}$ and $5 \mathrm{r} / \mathrm{min}$. For the optimized slotted borehole, the parameters were $26 \mathrm{MPa}$ and $4 \mathrm{r} / \mathrm{min}$. Optimization was carried out as follows: the water jet pressure increased by $1 \mathrm{MPa}$ every $2 \mathrm{~min}$ starting from $20 \mathrm{MPa}$. When the water discharge from the borehole started to decrease, it was considered that the coal slag had begun blocking the borehole and preventing the water pressure boost. Thus, the water pressure was the optimized pump pressure. The rotational speed can be optimized in the same manner. These boreholes were located at the same drill site, with a drilling spacing of $10 \mathrm{~m}$. The geological column and borehole layout parameters are shown in Figure 12.
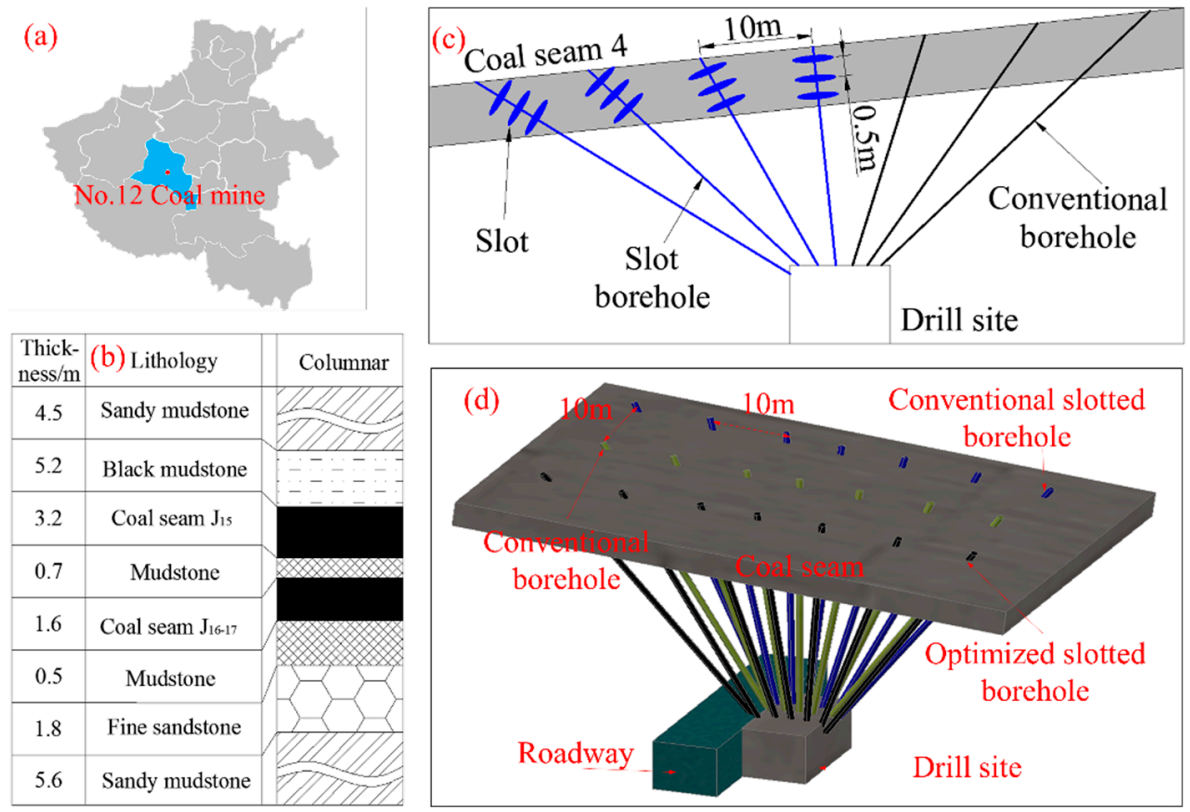

Figure 12. Detailed description of test site and borehole layout parameters: (a) location of No. 12 Coal Mine; (b) geologic column; (c) plan sketch of boreholes; (d) schematic diagram of boreholes. 


\subsection{Application Effect}

As shown in Figure 13, the extraction rate of the optimized slotted borehole was 1.3 times that of the conventional slotted borehole, and the extraction rate of the conventional slotted borehole was 3.8 times that of the conventional borehole. The average gas extraction rate of the optimized slotted borehole, conventional slotted borehole, and conventional borehole was $0.73 \mathrm{~m}^{3} / \mathrm{min}, 0.55 \mathrm{~m}^{3} / \mathrm{min}$, and $0.14 \mathrm{~m}^{3} / \mathrm{min}$, respectively. The average gas extraction rate over one month was calculated as shown in Figure 14. The variation trends of the gas extraction rate were approximately the same for the two borehole types. The trend gradually decreased as the extraction time increased, and the reduction rate gradually decreased. According to the overall trend, the gas extraction rate after slotting was always higher than that of the conventional borehole, which was approximately 3-4 times equal that of the conventional borehole.

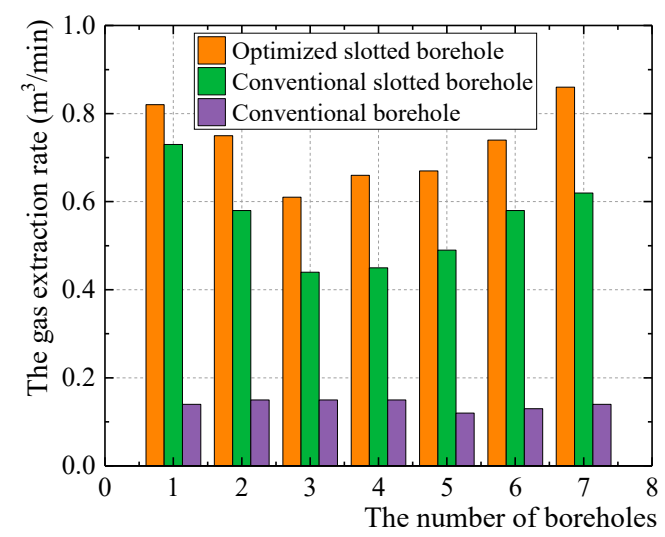

Figure 13. Gas extraction rate of different boreholes.

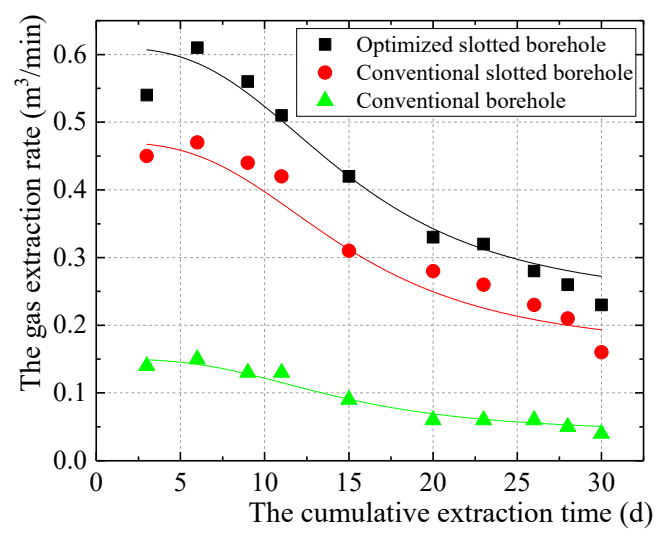

Figure 14. Variation curve of gas extraction rate.

Moreover, it was found that a borehole with a small angle to the coal seam had a high gas drainage flow, mainly owing to the angle between the water jet impact direction and the coal bedding. An appropriate angle between the cleats and borehole makes it easier for cracks to form on both sides of the cleats, and increases the coal seam permeability. The results revealed that the slot greatly increased the coal seam permeability and enhanced the extraction effect. Additionally, the extraction rate of the optimized slotted borehole was higher, which confirms the results of the aforementioned analysis.

\section{Conclusions}

To investigate appropriate parameters for the application of hydraulic slotting technology in jointed coal reservoirs, we investigated the law governing the influence of conventional application parameters on the hydraulic slotting effect by conducting a numerical simulation and experimental 
testing. Thus, the permeability-enhancing mechanism was clarified. The conclusions drawn from this study are as follows:

(1) With the impact of the water jet, the cleats and joints in the coal generated stress concentration and initiated fractures. This promoted the formation of a complex fracture network. The optimized arrangement included angles between the borehole and the coal seam strike with an inclination of $20-45^{\circ}$, respectively. The cleats underwent tensile failure, and initiated and extended along the vertical direction of the cleats and joints.

(2) The water jet pressure and rotation speed determined the shape of the slot. The depth of the slot increased with the water jet pressure or with the decrease of rotation speed; however, the width of the slot was not greatly affected. High water jet pressure and low rotation speed promoted the formation of cracks at the end of the slot, which strengthened the permeability-enhancing effect. However, the coal fragments could more easily peel off from the sides of the seam, and subsequently blocked the borehole. The high water pressure and low rotation speed application parameters were optimized without blocking the borehole.

(3) The results of field application at the Pingdingshan No.12 Coal Mine revealed that the gas extraction flow after hydraulic slotting was approximately 3-4 times equal to that of conventional boreholes. After optimization, the gas extraction flow was 1.3 times equal to that of conventional hydraulic slotting. An appropriate angle between the cleats and the borehole can more effectively increase the permeability of the coal seam, and achieves higher gas drainage flow, as verified by the analysis results.

Author Contributions: Conceptualization, methodology and formal analysis, Z.G., S.Z. and Y.W.; resources, Y.L.; data curation, S.Z.; writing—original draft preparation, S.Z. and Y.W.; writing—review and editing, Z.G. and Y.L.; software, X.F.; investigation, X.F.; project administration, Y.W. and Y.L.; visualization, S.Z.; supervision, Z.G.; all authors read and approved the final manuscript.

Funding: This study was financially supported by the National Natural Science Foundation of China (NSFC) (Grant No. 51774055 and No. 51625401) and the National Science and Technology Major Projects of China (Grant No. 2016ZX05045).

Conflicts of Interest: The authors declare no conflict of interest.

\section{References}

1. Karacan, C.O.; Ruiz, F.A.; Cote, M.; Phipps, S. Coal mine methane: A review of capture and utilization practices with benefits to mining safety and to greenhouse gas reduction. Int. J. Coal Geol. 2011, 86, 121-156. [CrossRef]

2. Liu, X.F.; Song, D.Z.; He, X.Q.; Nie, B.S.; Wang, L.K. Insight into the macromolecular structural differences between hard coal and deformed soft coal. Fuel 2019, 245, 188-197. [CrossRef]

3. Ritter, D.; Vinson, D.; Barnhart, E.; Akob, D.M.; Fields, M.W.; Cunningham, A.; Orem, W.; McIntosh, J.C. Enhanced microbial coalbed methane generation: A review of research, commercial activity, and remaining challenges. Int. J. Coal Geol. 2015, 146, 28-41. [CrossRef]

4. Moore, T.A. Coalbed methane: A review. Int. J. Coal Geol. 2012, 101, 36-81. [CrossRef]

5. Vedachalam, N.; Srinivasalu, S.; Rajendran, G.; Ramadass, G.A.; Atmanand, M.A. Review of unconventional hydrocarbon resources in major energy consuming countries and efforts in realizing natural gas hydrates as a future source of energy. J. Nat. Gas Sci. Eng. 2015, 26, 163-175. [CrossRef]

6. Towler, B.; Firouzi, M.; Underschultz, J.; Rifkin, W.; Garnett, A.; Schultz, H.; Esterle, J.; Tyson, S.; Witt, K. An overview of the coal seam gas developments in Queensland. J. Nat. Gas Sci. Eng. 2016, 31, $249-271$. [CrossRef]

7. Li, H.Y.; Lau, H.C.; Huang, S. China's coalbed methane development: A review of the challenges and opportunities in subsurface and surface engineering. J. Pet. Sci. Eng. 2018, 166, 621-635. [CrossRef]

8. Aguado, M.B.D.; Nicieza, C.G. Control and prevention of gas outbursts in coal mines, Riosa-Olloniego coalfield, Spain. Int. J. Coal Geol. 2007, 69, 253-266. [CrossRef] 
9. Zuo, S.J.; Ge, Z.L.; Zhou, Z.; Wang, L.; Zhao, H.Y. A Novel Hydraulic Mode to Promote Gas Extraction: Pressure Relief Technologies for Tectonic Regions and Fracturing Technologies for Nontectonic Regions. Appl. Sci. 2019, 9, 1404. [CrossRef]

10. Cheng, L.; Ge, Z.L.; Xia, B.W.; Li, Q.; Tang, J.R.; Cheng, Y.G.; Zuo, S.J. Research on Hydraulic Technology for Seam Permeability Enhancement in Underground Coal Mines in China. Energies 2018, 11, 427. [CrossRef]

11. Zhang, H.; Cheng, Y.P.; Liu, Q.Q.; Yuan, L.; Dong, J.; Wang, L.; Qi, Y.X.; Wang, W. A novel in-seam borehole hydraulic flushing gas extraction technology in the heading face: Enhanced permeability mechanism, gas flow characteristics, and application. J. Nat. Gas Sci. Eng. 2017, 46, 498-514. [CrossRef]

12. Shimizu, H.; Murata, S.; Ishida, T. The distinct element analysis for hydraulic fracturing in hard rock considering fluid viscosity and particle size distribution. Int. J. Rock Mech. Min. Sci. 2011, 48, 712-727. [CrossRef]

13. Lu, Y.Y.; Zuo, S.J.; Ge, Z.L.; Xiao, S.Q.; Cheng, Y.G. Experimental Study of Crack Initiation and Extension Induced by Hydraulic Fracturing in a Tree-Type Borehole Array. Energies 2016, 9, 514. [CrossRef]

14. Zheng, C.S.; Lin, B.Q.; Kizil, M.S.; Aminossadati, S.M.; Li, H.; Chen, Z.W. Analysis on the multi-phase flow characterization in cross-measure borehole during coal hydraulic slotting. Int. J. Min. Sci. Technol. 2018, 28, 701-705. [CrossRef]

15. Lin, B.Q.; Liu, T.; Zou, Q.L.; Zhu, C.J.; Yan, F.Z.; Zhang, Z. Crack propagation patterns and energy evolution rules of coal within slotting disturbed zone under various lateral pressure coefficients. Arab. J. Geosci. 2015, 8, 6643-6654.

16. Jiang, J.Y.; Yang, W.H.; Cheng, Y.P.; Lv, B.M.; Zhang, K.; Zhao, K. Application of Hydraulic Flushing in Coal Seams to Reduce Hazardous Outbursts in the Mengjin Mine, China. Environ. Eng. Geosci. 2018, 24, 425-440. [CrossRef]

17. Zhang, Y.J.; Zou, Q.L. A prediction model for the slot depth of high pressure water jet. Results Phys. 2018, 11, 1105-1109. [CrossRef]

18. Zou, Q.L.; Lin, B.Q.; Liu, T.; Zhou, Y.; Zhang, Z.; Yan, F.Z. Variation of methane adsorption property of coal after the treatment of hydraulic slotting and methane pre-drainage: A case study. J. Nat. Gas Sci. Eng. 2014, 20, 396-406. [CrossRef]

19. Zou, Q.L.; Lin, B.Q. Fluid-solid coupling characteristics of gas-bearing coal subjected to hydraulic slotting: An experimental investigation. Energy Fuels 2018, 32, 1047-1060. [CrossRef]

20. Simone, A.; Duarte, C.A.; Van der Giessen, E. A Generalized Finite Element Method for polycrystals with discontinuous grain boundaries. Int. J. Numer. Methods Eng. 2006, 67, 1122-1145. [CrossRef]

21. Belytschko, T.; Gracie, R.; Ventura, G. A Review of Extended/Generalized Finite Element Methods for Material Modelling. Model. Simul. Mater. Sci. Eng. 2009, 17, 043001. [CrossRef]

22. Prevost, J.; Sukumar, N. Faults simulations for three-dimensional reservoir-geomechanical Models with the extended finite element method. J. Mech. Phys. Solids 2015, 86, 1-18. [CrossRef]

23. Prevost, J. Two-way coupling in reservoir-geomechanical models: Vertex-centered Galerkin geomechanical model cell-centered and vertex-centered finite volume reservoir models. Int. J. Numer. Methods Eng. 2014, 98, 612-624. [CrossRef]

24. Liu, C.; Prevost, J.; Sukumar, N. Modeling branched and intersecting faults in reservoir-geomechanics models with the extended finite element method. Int. J. Numer. Anal. Methods Geomech. 2019. [CrossRef]

25. Rivas, E.; Esfahani, M.; Gracie, R. A two-dimensional eXtended Finite Element Method model of Discrete Fracture Networks: An eXtended Finite Element Method model of Discrete Fracture Networks. Int. J. Numer. Methods Eng. 2018, 117, 1263-1282. [CrossRef]

26. Zhang, J.G.; Zhang, J.J.; Zhou, Z. Investigation of a Self-Excited Pulsed Water Jet Slotting for Coal Roadway Driving. Adv. Eng. Res. 2016, 73, 475-481.

27. Lin, B.Q.; Yan, F.Z.; Zhu, C.J.; Zhou, Y.; Zou, Q.L.; Guo, C.; Liu, T. Cross-borehole hydraulic slotting technique for preventing and controlling coal and gas outbursts during coal roadway excavation. J. Nat. Gas Sci. Eng. 2015, 26, 518-525. [CrossRef]

28. Kong, X.G.; Wang, E.Y.; Liu, X.F.; Li, N.; Chen, L.; Feng, J.J.; Kong, B.; Li, D.X.; Liu, Q.L. Coupled analysis about multi-factors to the effective influence radius of hydraulic flushing: Application of response surface methodology. J. Nat. Gas Sci. Eng. 2016, 32, 538-548. [CrossRef]

29. Ge, Z.; Li, S.; Zhou, Z.; Lu, Y.; Xia, B.; Tang, J. Modeling and experiment on permeability of coal with hydraulic fracturing by stimulated reservoir volume. Rock Mech. Rock Eng. 2019, 52, 2605-2615. [CrossRef] 
30. Liu, Y.L.; Xu, H.; Tang, D.Z.; Mathews, J.P.; Zhai, Y.Y.; Hou, W.; Li, S.; Tao, S.; Xiong, X.Y.; Wang, W. The impact of the coal macrolithotype on reservoir productivity, hydraulic fracture initiation and propagation. Fuel 2019, 239, 471-483. [CrossRef]

31. Xu, B.X.; Li, X.F.; Haghighi, M.; Ren, W.N.; Du, X.Y.; Chen, D.; Zhai, Y.Y. Optimization of hydraulically fractured well configuration in anisotropic coal-bed methane reservoirs. Fuel 2013, 107, 859-865. [CrossRef]

32. Li, Y.W.; Jia, D.; Wang, M.; Liu, J.; Fu, C.K.; Yang, X.L.; Ai, C. Hydraulic fracturing model featuring initiation beyond the wellbore wall for directional well in coal bed. J. Geophys. Eng. 2016, 13, 536-548. [CrossRef]

33. Ni, H.J.; Wang, R.H.; Zhang, Y.Q. A damage model for rock under high pressure water jet. Eng. Mech. 2003, 20, 59-62. (In Chinese)

34. Liang, S.; Ren, X.; Li, J. A mesh-size-objective modeling of quasi-brittle material using micro-cell informed damage law. Int. J. Damage Mech. 2018, 27, 913-936. [CrossRef]

35. Zhou, L.; Wang, C.; Zhang, X. Finite element simulation of hot rolling process for SiCp/Al composites. Acta Metall. Sin. 2015, 51, 889-896. (In Chinese)

36. Crastiu, I.; Pop-Gozman, C.; Deac, S. The influence of the mesh element size on the natural frequencies of beam. In Proceedings of the 2018 IEEE 16th International Symposium on Intelligent Systems and Informatics (SISY), Subotica, Serbia, 13-15 September 2018; pp. 137-142.

37. Dehkhoda, S.; Hood, M. An experimental study of surface and sub-surface damage in pulsed water-jet breakage of rocks. Int. J. Rock Mech. Min. Sci. 2013, 63, 138-147. [CrossRef]

38. Lu, Y.Y.; Xiao, S.Q.; Ge, Z.L.; Zhou, Z.; Ling, Y.F.; Wang, L. Experimental study on rock-breaking performance of water jets generated by self-rotatory bit and rock failure mechanism. Powder Technol. 2019, 346, 203-216. [CrossRef]

(C) 2019 by the authors. Licensee MDPI, Basel, Switzerland. This article is an open access article distributed under the terms and conditions of the Creative Commons Attribution (CC BY) license (http://creativecommons.org/licenses/by/4.0/). 